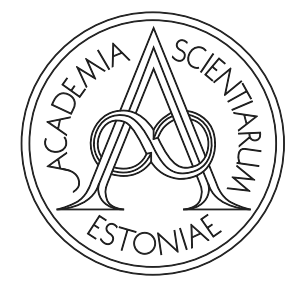

Proceedings of the Estonian Academy of Sciences,

$2021,70,4,477-483$

https://doi.org/10.3176/proc.2021.4.15

Available online at www.eap.ee/proceedings

MANUFACTURING

ENGINEERING

\title{
Experimental evaluation and numerical modelling of the quality of photovoltaic modules
}

\author{
Pavel Tšukrejev*, Kristo Karjust and Jüri Majak \\ Department of Mechanical and Industrial Engineering, Tallinn University of Technology, Ehitajate tee 5, Tallinn, Estonia
}

Received 2 July 2021, accepted 20 July 2021, available online 9 November 2021

(C) 2021 Authors. This is an Open Access article distributed under the terms and conditions of the Creative Commons AttributionNonCommercial 4.0 International License (http://creativecommons.org/licenses/by-nc/4.0/).

\begin{abstract}
All over the world a rapid increase in demand for photovoltaic system installations has generated an outstanding growth in production numbers in the manufacturing facilities of photovoltaic (PV) systems. Production companies are facing challenges in providing the best quality along with rising manufacturing quantities. Due to the underlying technology not all the quality decisions can be made in real time. This research is focused on the development of experimental study and mathematical modelling of the quality control parameters for PV modules, which could only be tested during chemical processes and not be monitored constantly by operators at the production line.
\end{abstract}

Key words: production monitoring, photovoltaic modules, Haar wavelets, artificial neural network.

\section{INTRODUCTION}

Smart manufacturing shows the direction for production companies to stay competitive on the market and to deliver the maximum return on assets. The companies have to continuously search for innovative ways to improve their production and quality control processes, to optimize manufacturing processes using new I4.0 based technologies and perform work in a faster and better way $[1,2]$. Production processes should be effectively monitored and controlled to avoid malfunction and unplanned downtime.

Product quality is becoming an increasingly important function for the company due to the increased customer demands and product quality requirements. The manufacturing company has to deal with the increasing number of data and alternatives to be decided during on-time or off-time process, as well as with product quality control. As regards the latter, usually the fully dedicated data experts and expensive information technology solutions are not readily available, making it very hard to track the important and process related information which should be gathered and used for optimization. Manufacturing companies apply modern quality control techniques to improve the production line and the quality of its processes, and through that also the final end product quality [3]. A range of techniques are available to control product or process quality. These include seven statistical process control (SPC) tools, acceptance sampling, quality function deployment (QFD), failure mode and effects analysis (FMEA), six sigma, and design of experiments (DoE). Quality control (QC) and quality assurance (QA) can be defined as meeting the specification or customer requirements without any defect. A product is said to be high in quality if it is functioning as

\footnotetext{
${ }^{*}$ Corresponding author, pavel.tsukrejev@taltech.ee
} 


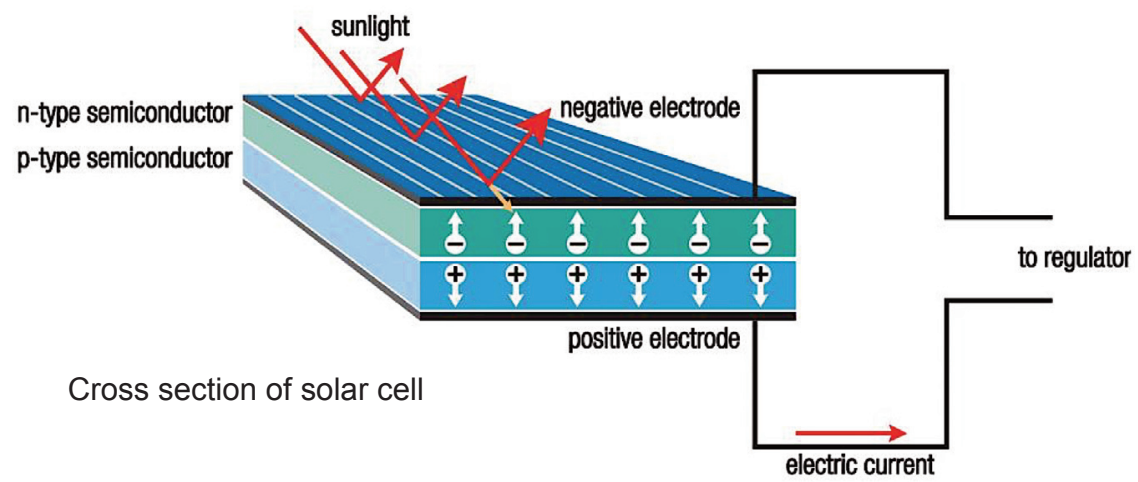

Fig. 1. Schematic cross section of c-Si solar cell [5].

expected and is reliable. Quality control refers to activities ensuring that produced items meet the highest possible quality level.

The volumes of installations of photovoltaic (PV) modules are rapidly growing annually. The global compound annual growth rate of cumulative photovoltaic installations during the period from 2010 to 2019 was as high as $35 \%$ [4]. Photovoltaic modules utilize the photovoltaic effect that generates flow of electrons inside the materials which are exposed to light. Different materials can be used for achieving the photoelectric effect. Currently the most popular way of manufacturing (due to efficiency, price and manufacturability) PV modules is by using the silicon-based solar cells. According to [4], 95\% of manufactured modules are built on silicon-based solar cells. The simplified cross section of a solar cell and the PV principle are presented in Fig. 1.

Different materials are employed to build a PV module, in order to ensure maximization of light gathering, structural health as well as electric and climate insulation. The structure of a PV module includes several components [6]:

- Front sheet - glass or some other transparent material for light transparency as well as for climate and mechanical protection;

- Photovoltaic cells - for current generation;

- Ribbon connections - for electrical circuit;

- Back sheet - for electrical and climate insulation;

- Encapsulant - for laminating everything together, protection from moisture and air as well as being transparent for light.

The current work collects the experimental data in real time, and based on these data builds mathematical model(s) for prediction of the quality of encapsulant gel content. The obtained results will allow manufacturers to predict the crosslinking level instantly on site on the basis of real measured parameters and increase the feedback of the final end product quality.

\section{EXPERIMENTAL EVALUATION OF THE QUALITY OF ENCAPSULANT}

Quality of lamination is a general focus of a series of papers and an emerging problem for solar companies. The encapsulant under study is ethylene/vinyl acetate (EVA), as it is mainly used by the partner PV manufacturer of this study.

For particular research assessment, lamination success could be divided into two main categories, as presented in Fig. 2:

1. Visual component - all possible visual faults that lead to bigger issues in the future.

2. Quality of encapsulant (crosslinking level) - gel content of the EVA material, should be defined during the time-consuming process [7]. 


\section{EVA lamination quality assessment}

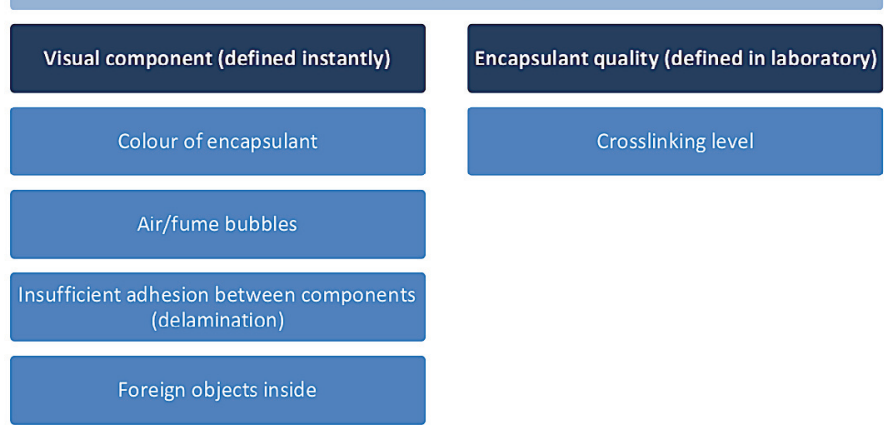

Fig. 2. Quality assessment of cured ethylene/vinyl acetate.

Ensuring the quality of encapsulant is challenging due to the lack of possibilities to assess and evaluate the quality of lamination on the chemical composition level right after the lamination cycle is completed. In order to define the crosslinking level, laboratory tests are needed. A good cross-linking level is considered to be $65 \%$ [8]. The supplier of EVA suggests the target value for PV modules to be between $70 \%$ and $80 \%$. Sample gathering is a process that makes a PV module non-usable later.

There are a number of inputs that impact the quality of the lamination process [9]: temperature, duration, pressure/vacuum time. As according to us, temperature and duration of the process have the greatest impact on the quality of encapsulation, we decided to measure the temperature from the edge of the module during the real manufacturing lamination cycle. Previous experience has shown that measuring from the surface of the module is damaging to the back sheet and the module becomes visually defected and non-usable.

External equipment was employed in order to measure the temperature in real time with the possibility to trace everything via online cloud-based graphical user interface. During the experimental phase of measuring temperature by external equipment, the research group faced the fact that there was a difference between the real measured temperature from the module and the temperature shown by the lamination machine, which is demonstrated in Fig. 3. Also, there was dependence on temperature difference related to the time the lamination occurred: first laminations after the startup, numerous continuous laminations or lamination after a long pause. This is a point of interest to the PV manufacturer as the need has arisen to tune the receipts used in production.

The dataset used includes 16 different values, 2-3 repetitive tests were performed for each value (see Table 1). It should be mentioned that the mesh-points have non-uniform distribution.

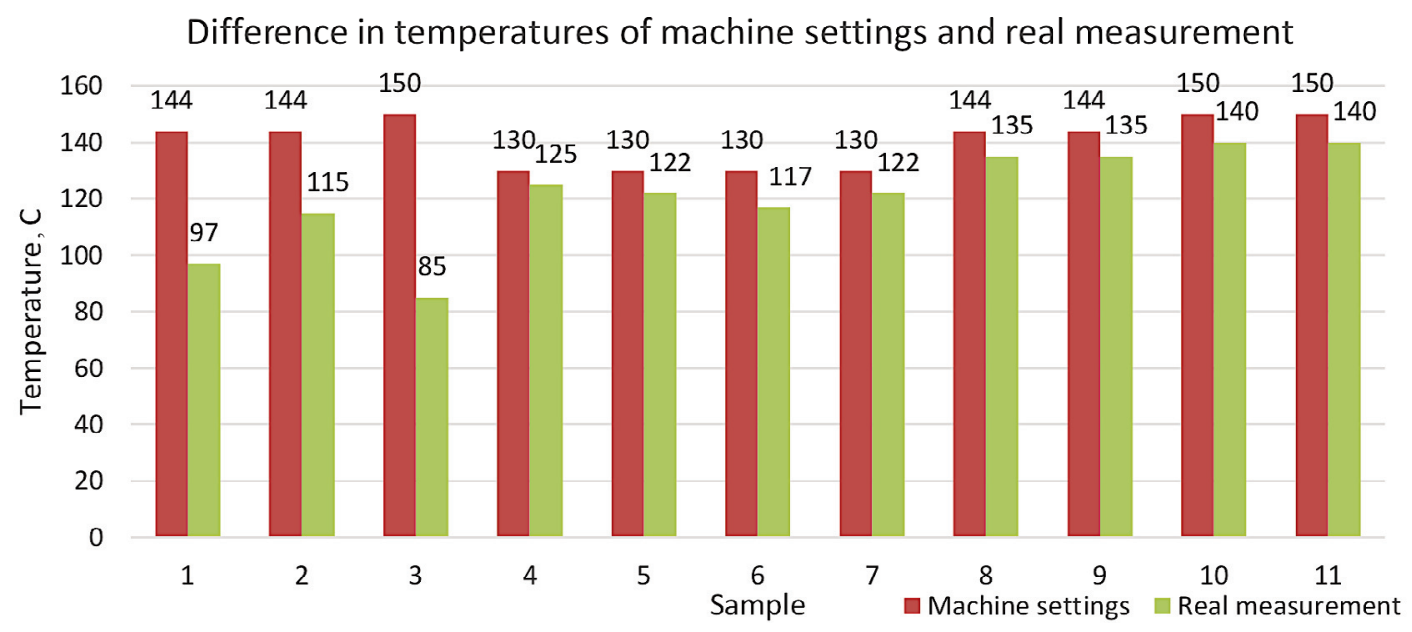

Fig. 3. Difference between machine measured temperature against real measurement from the module edge. 
Table 1. Gel content dependence on temperature and processing time

\begin{tabular}{l|cccc}
\hline No. & Temperature, C & Total processing time (s) & Gel content, \% \\
\hline 1 & 130 & 870 & 57.6 \\
2 & 130 & 1025 & 58.4 \\
3 & 130 & 1172 & 59.2 \\
4 & 130 & 1320 & 59.9 \\
5 & 137 & 870 & 56.4 \\
6 & 137 & 1025 & 61.6 \\
7 & 137 & 1172 & 62.7 \\
8 & 137 & 1320 & 63.9 \\
9 & 144 & 870 & 55.2 \\
10 & 144 & 1025 & 64.8 \\
11 & 144 & 1172 & 66.3 \\
12 & 144 & 1320 & 67.9 \\
13 & 150 & 870 & 70.7 \\
14 & 150 & 1025 & 81.1 \\
15 & 150 & 1172 & 81.8 \\
16 & 150 & 1320 & 82.5
\end{tabular}

Only test data with the gel content value over $50 \%$ are considered.

\section{NUMERICAL MODELS}

The following two numerical models are presented for describing the dependence of the gel content on the processing time and the temperature measured by external sensor.

\section{Artificial neural network-based model}

In engineering design, the emerging growth in the use of artificial intelligence (AI) tools and methods can be observed $[10,11]$. In the current study, the artificial neural network (ANN) model was utilized. It is well known that in the case of a limited dataset available (see Table 1), the feedforward ANN with one hidden layer is satisfactory. The tuning of the ANN was performed on the dataset provided in Table 1. The Levenberg-Marquardt training algorithm was applied. The nonlinear tansig and linear purelin transfer functions were utilized in hidden and output layers, respectively. The optimal configuration of the ANN was found with only four neurons in the hidden layer. The mean squared error of the developed ANN model is given in Fig. 4.

The accuracy achieved is satisfactory, since the test data still include the measuring error. Nevertheless, a problem exists that different runs of the ANN model generate slightly different results. This issue is caused by the fact that in the ANN model the initial weights were generated at random and if the dataset is not sufficiently big, the final models and their accuracy may differ. Thus, the preliminary results were obtained, but the ANN model needs an improved dataset.

\section{Haar wavelet-based model}

The following provides an alternative approach using the existing dataset. More generally, the $n$-th order derivative of the function can be expanded into Haar wavelets as 


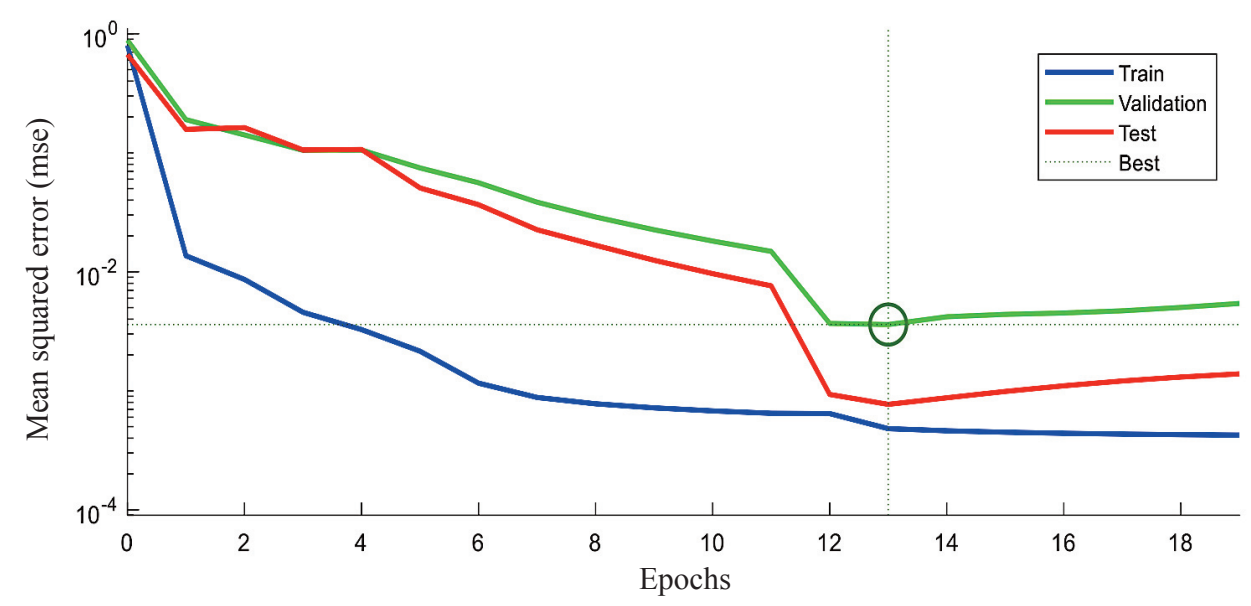

Fig. 4. The mean squared error of the ANN model.

$$
f^{(n)}(x, y)=\sum_{i=1}^{2 M} \sum_{j=1}^{2 M} a_{i j} h_{i}(x) h_{j}(y)
$$

Herein the gel content function $f(x, y)$ is expanded directly into Haar wavelets as

$$
f(x, y)=\sum_{i=1}^{2 M} \sum_{j=1}^{2 M} a_{i j} h_{i}(x) h_{j}(y)
$$

i.e. the simplest case, where $n=0$ is used. In the case of $n \geq 1$, the accuracy of the Haar wavelet model will increase with the increasing $n$ value, but extra test data is required for determining the integrating constants (functions).

In (1)-(2) $a_{i j}$ are unknown coefficients, $x$ and $y$ are design variables. The Haar functions are defined as

$$
h_{i}(x)=\left\{\begin{array}{ccc}
1 & \text { for } & x \in\left[\xi_{1}(i), \xi_{2}(i)\right) \\
-1 & \text { for } & x \in\left[\xi_{2}(i), \xi_{3}(i)\right) \\
0 & \text { elsewhere } &
\end{array}\right.
$$

where $i=m+k+1, m=2^{j}$ is the maximum number of square waves deployed in interval $[A, B]$ and the parameter $k$ indicates the location of the particular square wave,

$$
\xi_{1}(i)=A+2 k \mu \Delta x, \xi_{2}(i)=A+(2 k+1) \mu \Delta x, \xi_{3}(i)=A+2(k+1) \mu \Delta x, \mu=M / m, \Delta x=(B-A) /(2 M), M=2^{J},
$$

where $j=0.1, \ldots, J$ and $k=0.1, \ldots, m-1$ stand for dilatation and translations parameters, respectively. Note that equations (1) and (2) correspond to the higher order method and the widely used Haar wavelet method, respectively [12].

As pointed out above, in the case of limited dataset, the ANN model has some drawbacks and the Haar wavelet-based deterministic model can be preferred. In most applications the Haar wavelet method is used with a uniform mesh. However, the test data given in Table 1 correspond to a non-uniform mesh. In the latter case the Haar matrices derived for a uniform mesh are not applicable. Instead, the Haar functions can be evaluated by using formula (3). The accuracy achieved utilizing a Haar wavelet-based model relies on the same range as that of the ANN. Here, the gel content does not have one fixed target value but its desired 
value is in the range of $70-80 \%$. Further optimization of the gel content can be performed by taking the target value of $75 \%$ and employing the traditional gradient based and global optimization methods [13-18].

\section{CONCLUSIONS}

The external measurement equipment has been elaborated for measuring temperature in real time. Furthermore, it has been observed that the real measured temperature from the module and the temperature shown by the lamination machine differ. The temperature and process duration are considered for the modelling quality of the gel content. The two mathematical models, feedforward ANN and Haar wavelet models, have been developed. For the given dataset the accuracy of both models lies in the same range. However, the deterministic Haar wavelet method can be preferred since the ANN model varies in different runs. Implementation of the higher order Haar wavelet method requires extra design experiment with the required test points within the boundary of the design domain.

In further study it is planned to measure the pressure/vacuum conditions directly from the lamination chamber without relying on machine data, embedding a wireless sensor inside the PV module.

\section{ACKNOWLEDGEMENTS}

The authors would like to thank the Innovation Framework for Challenge Oriented Intelligent Manufacturing (INforM) funded by the INTERREG programme; the Estonian Centre of Excellence in Zero Energy and Resource Efficient Smart Buildings and Districts, ZEBE, grant TK146 funded by the European Regional Development Fund, AR20013 Smart City Centre of Excellence (1.01.2020-31.08.2023). The research was conducted using the Smart Industry Centre (SmartIC) core facility funded by the Estonian Research Council grant TT2. The publication costs of the article were covered by the Estonian Academy of Sciences and Tallinn University of Technology.

\section{REFERENCES}

1. Sell, R. and Otto, T. Remotely controlled multi robot environment. In Proceedings of the 2008 19th EAEEIE Annual Conference, Tallinn, Estonia, June 29-July 2, 2008. IEEE, 20-25. https://doi.org/10.1109/EAEEIE.2008.4610152

2. Kuts, V., Otto, T., Tähemaa, T., Bukhari, K. and Pataraia, T. Adaptive industrial robots using machine vision. In Proceedings of the ASME 2018 International Mechanical Engineering Congress and Exposition, Pittsburgh, PA, USA, November 9-15, 2018. ASME, V002T02A093. https://doi.org/10.1115/IMECE2018-86720

3. Judi, H. M., Jenal, R. and Genasan, D. Quality control implementation in manufacturing companies: motivating factors and challenges. In Applications and Experiences of Quality Control (Ivanov, O., ed.). InTech, 2011, 495-508. https://doi.org/10.5772/15997

4. Photovoltaics Report. Fraunhofer Institute for Solar Energy Systems ISE, 16 September 2020.

5. Crystal Solar Energy. https://www.crystalsolarenergy.com.au/types-of-solar-panels-which-one-is-the-best-choice (accessed 202106-29).

6. Satpathy, R. and Pamuru, V. Solar PV Power. Academic Press, Cambridge, MA, 2020.

7. Jaunich, M., Böhning, M., Braun, U., Teteris, G. and Stark, W. Investigation of the curing state of ethylene/vinyl acetate copolymer (EVA) for photovoltaic applications by gel content determination, rheology, DSC and FTIR. Polym. Test., 2016, 52, $133-140$.

8. Chinnadurai, T., Nalajam, P. and Arungalai Vendan, S. Analysis of mechanical and thermal behaviors for cross linked ethylene vinyl acetate (EVA) protective film employed for PV cells. Mater. Today: Proc., 2018, 5(11), 23369-23374.

9. Tšukrejev, P., Kruuser, K. and Karjust, K. Production monitoring system development for manufacturing processes of photovoltaic modules. Proc. Est. Acad. Sci., 2019, 68(4), 401-406. https://doi.org/10.3176/proc.2019.4.09

10. Kaganski, S., Majak, J. and Karjust, K. Fuzzy AHP as a tool for prioritization of key performance indicators. Procedia CIRP, 2018, 72, 1227-1232. https://doi.org/10.1016/j.procir.2018.03.097

11. Paavel, M., Karjust, K. and Majak, J. PLM Maturity model development and implementation in SME. Procedia CIRP, 2017, 63, 651-657. https://doi.org/10.1016/j.procir.2017.03.144

12. Majak, J., Shvartsman, B., Ratas, M., Bassir, D., Pohlak, M., Karjust, K. and Eerme, M. Higher-order Haar wavelet method for vibration analysis of nanobeams. Mater. Today Commun., 2020, 25, 101290. https://doi.org/10.1016/j.mtcomm.2020.101290 
13. Zhu, J., Zhang, W., Xia, L., Zhang, Q. and Bassir, D. Optimal packing configuration design with finite-circle method. J. Intell. Robot. Syst., 2012, 67(3-4), 185-199.

14. Zhang, W. H., Domaszewski, M. and Bassir, H. Developments of sizing sensitivity analysis with the ABAQUS code. Struct. Optim., 1999, 17(2), 219-225.

15. Guessasma, S., Bassir, D. and Hedjazi, L. Influence of interphase properties on the effective behaviour of a starch-hemp composite. Mater. Des., 2015, 65, 1053-1063.

16. Nahas, M. and Alzahrani, M. Optimal stochastic distribution of CNTS in a cantilever polymer microbeam using artificial neural networks. Mech. Compos. Mater., 2020, 56(5), 665-672.

17. Cui, D. and Li, D. K. Optimization of extension-shear coupled laminates based on the differential evolution algorithm. Mech. Compos. Mater., 2019, 54(6), 799-814.

18. Plotnikova, S. V. and Kulikov, G. M. Shape control of composite plates with distributed piezoelectric actuators in a threedimensional formulation. Mech. Compos. Mater, 2020, 56(5), 557-572.

\section{Päikesepaneeli moodulite kvaliteedi eksperimentaalne hindamine ja numbriline modelleerimine}

\section{Pavel Tšukrejev, Kristo Karjust ja Jüri Majak}

Päikesepaneeli mooduli temperatuuri täpsemaks mõõtmiseks reaalajas on välja töötatud riistvara- ja tarkvaralahendus. Mõõtmistulemuste analüüs näitas, et väljatöötatud seadme abil mõõdetud temperatuur moodulis erineb mõnevõrra lamineerimismasina mõõdetud temperatuurist. Töös uuriti etüleen-vinüülatsetaadi kihi geelisisaldust mõjutavaid parameetreid ja valiti välja kaks olulisemat mõjutegurit: temperatuur ja lamineerimisprotsessi aeg. Geeli sisalduse kirjeldamiseks koostati kaks matemaatilist mudelit: tehisnärvivõrkude ja Haari lainikute kasutamisel põhinevad mudelid. Mõlemaid mudeleid on lihtne kasutada, kuid tehisnärvivõrkude mudel sõltub juhuslikkusest ja andmehulga väiksuse tõttu olid eri käivitustel saadud tulemused erinevad. Seega antud andmehulga korral võib eelistada Haari lainikute kasutusel põhinevat mudelit. Kõrgemat järku lainikute meetodi rakendamine eeldab selleks kohandatud katsete planeerimist. Edasistes uuringutes on kavas integreerida juhtmeta andur päikesepaneeli moodulisse ja mõõta rõhu/vaakumi tingimusi otse lamineerimiskambrist. 